\title{
Home-field advantage of litter decomposition faded 5-10 years after spruce forest clearcutting
}

\author{
Liyan Zhuang ${ }^{1}$, Andrea Schnepf ${ }^{1}$, Kirsten Unger $^{2}$, Ziyi Liang $^{1,3,}{ }^{*}$ and Roland Bol ${ }^{1}$ \\ ${ }^{1}$ Forschungszentrum Jülich, Agrosphäre (IBG-3), 52428 Jülich, Germany \\ ${ }^{2}$ Institute of Crop Science and Resource Conservation (INRES), Soil Science and Soil Ecology, University of Bonn, Nussallee 13, \\ 53115 Bonn, Germany \\ ${ }^{3}$ Long-term Research Station of Alpine Forest Ecosystems, Key Laboratory of Ecological Forestry Engineering, Institute of \\ Ecology and Forestry, Sichuan Agricultural University, Chengdu 611130, China \\ *Corresponding author.chn_liangzy@163.com.
}

\section{Abstract:}

Home-field advantage (HFA) encompasses all the processes leading to faster litter decomposition in the 'home' environment as compared to that of 'away' environments. To determine the occurrence of HFA in a forest and adjacent clear-cut, we set up a reciprocal litter decomposition experiment within the forest and clear-cut for two soil types (Cambisols and Gleysols) in temperate Germany. The forest was dominated by Norway spruce (Picea abies), whereas forest regeneration of European Beech (Fagus sylvatica) after clearcutting was encouraged. Our observation that Norway spruce decomposed faster than European beech in 70-yr-old spruce forest, was therefore most likely related to specialized litter-microbial interaction under existing spruce, and leading to a HFA. The 'spruce' microbial biome and soil conditions of original forest were then rapidly changed even after a short-term regeneration following clearcutting, resulting in faster beech decomposition also masking any HFA for spruce, particularly in moisture- and nutrient-deficient Cambisols. Divergence between forest and clear-cut in the Cambisol of their litter $\delta^{15} \mathrm{~N}$ values beyond 9 months, implied litter $\mathrm{N}$ decomposition was only initially independent of soil and residual $\mathrm{C}$ status

We conclude that clearcutting modifies HFA and helps promote the establishment or regeneration of European beech in this and similar forest mountain upland areas.

Keywords: Clearcutting; Norway spruce; European beech; litter decomposition; N; Ca; Home-field advantage (HFA); Carbon and nitrogen stable isotopes 


\section{Introduction}

Forest cover change contributes to complex feedbacks on forest ecosystems along chronosequences [1] and results in the disruption of ecological processes, including microclimate and soil nutrients mineralization [2-4]. Clearcutting, changing the dominated species and forest growth dynamics leaves behind a significant shift in ecosystem scale species communities, influence on the decomposition pattern during regeneration. Such as, nutrient-rich litter or logging residual in early successional stages is associated with faster decomposition and turnover rates, while slower organic matter recycling and infertile soil has usually found under older forest $[5,6]$. The change in decomposition process determines organic matter sequestration and hence forest growth in forest ecosystems [7]. A better understanding of litter decomposition and nutrients cycling is necessary for an effective management strategy to promote forest regeneration, especially after deforestation or after decades of regeneration [8].

In the last century, large forest areas in central Europe were converted into monocultures of fast-growing spruce. Spruce monocultures are generally known for their low biodiversity and soil deterioration due to acidification and nitrogen leaching $[9,10]$. To maintain the ecological, sociological, and cultural functions of the forest, the conversion of existing Norway spruce into more natural broadleaved and mixed forests is the main silvicultural aim in Germany and other European countries $[11,12]$. Some studies have shown that spruce decomposition was accelerated in its originated coniferous stands relative to away from it [13-15]. It is usually considered that soil decomposer organisms may adapt to break down particular substrate in individual ecosystems, thereby accelerating the decomposition of litter from which it is derived (i.e. home) than away from that plant $[16,17]$, which has been termed the home field advantage (HFA) of litter decomposition [18].

Moreover, the data review analysis from Ayres et al. [19] concluded that HFA is widespread in forest ecosystems and suggested that $\sim 30 \%$ of the variability of litter decomposition at a global scale can be explained by HFA. As such, clearcutting brings about a high plant abundance of pioneer species (i.e., high nutrient concentration and low lignin: $\mathrm{N}$ ratios) and modified soil abiotic conditions (including nutrient 
leaching, soil temperature, moisture, and $\mathrm{pH}$ ) [20-23], resulting in shifts in functioning of decomposer communities and higher population of soil microbial community $[24,25]$. The resultant association between individual species and site condition have the potential to produce effects on soil properties that enhanced the decomposition of its own litter, with plant-soil interactions, creating a HFA effect for the species-own litter [24]. Case studies indicated that warmer and moister conditions after clearcutting drive faster litter breakdown by higher soil decomposer activity irrespective of HFA [26,27]. After clearcutting, intimate litter-soil-decomposer interaction develops with regeneration through local adaption or dispersal [28], however, studies rarely investigate HFA after removing the dominant species as in clearcuttings. there is a need for gathering reliable scientific knowledge on the influence of clearcutting on original' home' and 'away' litter decomposition in the new clear-cut.

There is increasing evidence that the strength of HFA is associated with the interaction between local litter quality and specilized microbes. For example, fungal-dominated communities tends to be more abundant for degradaing recalcitrnt and low-quality litter, in contrast, high-quality litter is more likely ro gennerat an HFA by bacterial-dominated communities for degrading labile compunds [29,30]. Moreover, across succession, soil communities have went through a wider range of litter qualities contributing to a broader functional capacity to degradate various litter types [28], so HFA may increase with regeneration. However, rencent studies pointed out that litter quality were not important determinace of HFA [31], while the greater dissimlarity between 'home' and 'away' litter indicated strong HFA [32].

Measurements of plant $\delta^{13} \mathrm{C}$ and $\delta^{15} \mathrm{~N}$ abundance have been shown to be useful indicators of forest organic matter dynamics [33]. The difference between the isotopic signature of residual litter and litter degradation or litter nutrient dynamics are considered as the inherent tracers for understanding the progression of decomposition and nutrient mineralization/immobilization [34]. Labile compounds exhibit higher $\delta^{13} \mathrm{C}$ values than $\delta^{13} \mathrm{C}$-depleted recalcitrant lignin considered to turn over slower [35]. In addition, microbial processes enrich carbon with $\delta^{13} \mathrm{C}$ in relation to bulk litter [36]. The changes in residual $\delta^{15} \mathrm{~N}$ values are positively associated with nitrate leaching following forest clearcutting [37], that is, bacteria- 
dominance may decrease $\delta^{15} \mathrm{~N}$ signatures through immobilization of nitrate depleted in $\delta^{15} \mathrm{~N}$. In N-rich ecosystems (particular sites with elevated soil nitrification), less dependent on $\mathrm{N}$ derived from mycorrhizal fungi [38], have been reported to have higher litter $\delta^{15} \mathrm{~N}$ values and $\delta^{15} \mathrm{~N}$-enrichement factors [37]. These findings have provided us with a meaningful point that the alteration of isotopic $\mathrm{C}$ and $\mathrm{N}$ signature between litter types during decomposition are useful indicators of nutrient status after disruption of the forest.

In the Eifel National Park (Germany), clearcutting operations were carried out in spruce monoculture in 2013 as the first step of conversion from planted spruce monoculture to natural forest. This significantly affected soil nutrient leaching [39,40], moisture [41] as well as soil respiration [42]. To test the validity of the HFA change long with clearcutting management. We carried out a field litter decomposition on a 70-yr spruce forest and a clear-cut after short-term (8-yr) regeneration. In addition, we tested the importance of litter quality on the strength/occurrence of HFA. The difference of litter mass loss and nutrient release as well as isotopic $\delta^{13} \mathrm{C}$ and $\delta^{15} \mathrm{~N}$ discrimination between spruce and beech were determined to figure out this question.

\section{Materials and methods}

\section{Site description}

The study area is located in Wüstebach $\left(50^{\circ} 30^{\prime} 15.3^{\prime \prime} \mathrm{N}, 6^{\circ} 20^{\prime} 03.0^{\prime \prime} \mathrm{E}\right)$, situated within the Eifel National Park. The climate is mild and humid, with the mean annual air temperature of $7^{\circ} \mathrm{C}$ and the mean annual precipitation of about $1200 \mathrm{~mm}$ [43]. Winter is moderately cold with periods of snow. Norway spruce replaced European beech as the dominant canopy species for timber production since the 1940s. In the last decades, the Park authority has started to accelerate the 'natural' regeneration towards a beech forest by clearcuts of significant proportion of the Norway spruce monoculture ( $\sim 90 \%)$ [44]. The ground cover vegetation in these clearcut is formed mainly by young samplings of alder [Alnus glutinosa (L.) Gaertn], European beech (Fagus sylvatica) with an admixture of early pioneer species, i.e. scrubs, bushes after 8year regeneration. Norway spruce (Picea abies) is the dominant tree species in the uncut remaining forest. 
Five subplots were selected for this study ranging from $595 \mathrm{~m}$ in the northern part to $628 \mathrm{~m}$ in the south in forest and clear-cut, respectively. Soils at the stands are classified as Cambisols and Gleysols, and Gleysols nearby stream is moister than Cambisol. For more information about soil properties referring to Siebers and Kruse. [40] and Wiekenkamp et al. [42].

\section{Litter decomposition experiments}

Between 2019 and 2020, a reciprocal litter transplant experiment was established in the forest and clearcut. In September 2019, freshly senesced spruce needles and beech leaves were collected from 6 sampling sites at forest and clear-cut ecosystems, respectively. Within each collection, each substrate was collected from a minimum of 6 different plant individuals to ensure the representativeness of the pool collected. According to the purpose of the forest management, we assumed that spruce is the home environment for forest, while the home environment for beech is clear-cut.

All samples were air-dried to constant mass. $2.5 \mathrm{~g}$ of Spruce needles or Beech leaves were filled into each polyethylene litterbag $(10 \times 8 \mathrm{~cm} ; 0.25 \mathrm{~mm}$ mesh size $)$. The mesh size permits the entry of bacteria, fungi, and micro-fauna [45]. In October 2019, five sampling locations were selected for clear-cuts and adjacent forests. At each subplot, 7 litterbags of each species were placed on the upper soil layer after getting rid of the humus layer or grass. Litterbags were retrieved after 1, 3, 9, 12 months. Altogether, we prepared 160 litterbags ( 4 sampling times $\times 2$ stands $\times 2$ soil types $\times 2$ species $\times 5$ replicates $)$ in total. Harvested litterbags were transported to the laboratory. Oven-dried and weighed after removing soil particles and other extraneous materials.

$\mathrm{C}$ and $\mathrm{N}$ contents of each sampling were measured by a CNS analyzer. The natural abundance of $\delta^{13} \mathrm{C}$ and $\delta^{15} \mathrm{~N}$ was measured by stable isotope ratios mass spectrometry. The total phosphorus (P), Calcium (Ca) were determined after microwave digestion with $\mathrm{H}_{2} \mathrm{O}_{2}-\mathrm{HNO}_{3}$ using inductively coupled plasma mass spectrometry (ICP-MS).

\section{Data statistics}


To determine the strength and direction of home-field effects on litter decay rate, the home-field advantage index (HFAi) for mass loss and the release of C and $\mathrm{N}$ was calculated following Ayres et al. [19] and adapted from Veen et al. [31] as:

$$
\operatorname{HFAi}(\%)=\left(\frac{A_{R L_{a}}+B_{R L_{b}}}{2} / \frac{A_{R L_{b}}+B_{R L_{a}}}{2}\right) \times 100-100
$$

where $i_{R L_{j}}$ represents the relative mass or nutrient loss of species $i$ in environment $j$. Single sample $t$-test were used to test whether the HFAi differed from 0.

HFAi stands for the additional decomposition or mineralization at home versus away environment and is a net value for both species (A and B) in the reciprocal experiment.

The mean HFA (\% increase in $k$ value at home versus away environment) for each litter types was calculated according to [46]:

$$
\text { The mean HFA }=\left(k_{\text {home }}-k_{\text {away }}\right) / k_{\text {away }} \times 100
$$

where $k_{\text {home }}$ and $k_{\text {away }}$ are the decomposition constants of a given speceis at home and in away environments, respectively.

The $\delta^{13} \mathrm{C}$ and $\delta^{15} \mathrm{~N}$ values are expressed as:

$$
\delta(\% 0)=\left(\frac{R_{\text {sample }}}{R_{\text {standard }}}-1\right) \times 1000
$$

where $R_{\text {sample }}$ and $R_{\text {standard }}$ represents either ${ }^{13} \mathrm{C}:{ }^{12} \mathrm{C}$ or ${ }^{15} \mathrm{~N}:{ }^{14} \mathrm{~N}$ ratios of sample anf standard material, respectively. The stable isotope ratio values are expressed in parts per million (\%) relative to international standards. Vienna Pee Dee Belemnite (VPDB) for carbon isotope and atmospheric nitrogen for nitrogen isotopes. The analytical precisions for carbon isotopes $\pm 0.1 \%$ and $\pm 0.3 \%$ for nitrogen isotopes.

Mass remaining (\%) was calculated from dry mass at sampling date divided by initial dry mass. The decomposition rate $\left(k\right.$ value, $\left.\mathrm{yr}^{-1}\right)$ was estimated according to the exponential regression $y=e^{-k t}, y(\%)$ is mass remaining over time $t, k$ is the decomposition rate by Olson. [47]. Nutrients remaining (\%) of each 
sample were estimated as nutrient content at each sampling time divided by initial nutrient content and expressed by $\%$ of the initial amount. $T$-test were performed: 1 ) to test the significance of initial quality and residuals after one year of decomposition between beech and spruce; 2) to test $k$ values of beech and spruce in clear-cuts and forest on Cambisols and Gleysols; 3) to examine the environmental differences between forest and clear-cut at each sampling point; and finally 4) to determine if the HFAi was significant between soil types. Repeated measure ANOVAs were used to compare the significance of soil types, stands, and species on various nutrients remaining over time. Three-way ANOVAs were calculated to compare the three factors: soil types, stand, and species on nutrient remaining. Stepwise regression analysis indicated the variance relationship, like nutrients, and stoichiometry on mass loss between soil types, stands, and species. All statistical analysis was performed using SPSS22.0 for Windows software package.

\section{Results}

\section{Environmental difference between stands and soil}

Soil types and forest management greatly influence soil environmental conditions (Fig. 1). The soil moisture content was on average significantly higher in clear-cut than in the forest at both soil types, ranging from 36.6\%-55\%, and Cmabisols showed a larger difference in soil moisture by $8.7 \%$ than Gleysols by 2.7\%, comparing between clear-cut and forest. At both Cmabisols and Gleysols, soil temperature at forest floor was approximately $1^{\circ} \mathrm{C}$ higher in clear-cut than in forest. $T$-test revealed that the soil moisture and temperature conditions were mostly higher in clear-cut than forest with times, particularly at Cambisols.

\section{Initial litter quality and litter nutrients after one year of decomposition}

Initial litter quality differed between species. European beech had significantly better initial quality than Norway spruce, for $\mathrm{C}, \mathrm{N}, \mathrm{P}$ and $\mathrm{Ca}$, as well as lower $\mathrm{C}: \mathrm{N}$ and $\mathrm{C}: \mathrm{P}$ ratios (Table 1). After one year of decomposition, nutrients concentration and $\mathrm{C}$ stoichiometry were significantly different between species and stands. Most nutrients concentration decreased, except for the N, Fe, and C:P ratio. Furthermore, C concentration increased in the forest but decreased in clear-cuts for both species during decomposition. 


\section{The effect of home-field advantage on litter decomposition rates}

A significant home-field advantage was shown for the two soil types in this experiment (HFAi $=11$ at Cambisols and HFAi $=4$ at Gleysols, Table 2). A pattern of higher decomposition rate of the spruce in the original spruce forest after one year of decomposition followed by $k$ values (Fig. 2c, d). However, spruce has a lower 3-month $k$ value in forest than in clear-cut (Fig. 2a, b). There was no HFA between forest and clear-cut stands in the initial 3 months. The decomposition dynamic of beech litter differed from spruce in 3 months and 1 year of decomposition. Beech in clear-cut decomposed faster than in forest at Cambisols, but slower when decomposing in Gleysols. Moreover, after one year of decomposition, the $k$ value of beech in clear-cut decreased but was higher than forest stand at Cambisols, while the $k$ value of beech in Gleysols did not differ significantly.

The $k$ values for beech and spruce varied among stands and soil types with times. $k$ decreased in time for both spruce and beech The 3-month $k$ values were on average 2- to 3-fold higher compared to the 1year values (Fig. 2). The decomposition rate of spruce in the first three months was significantly higher than beech in most stands except for forest stand at Cambisols (Fig. 2a, b). Significantly or slightly higher $k$ value of spruce showed in forest at all plots except for clear-cut at Cambisols after one year of decomposition, when comparing with beech litter.

\section{$C$ and $N$ dynamics and their HFA}

Our results indicate that overall C and N release increased at "home" compared with "away" (Table 2). The difference on $\mathrm{C}$ release was stronger in Cambisols (14\% vs. 10\% in Gleysols) for spruce decomposed in forest, while HFA of $\mathrm{N}$ promoted a higher $\mathrm{N}$ release in Gleysols (43\%) than in Cambisols (28\%).

The significance of litter $\mathrm{C}$ dynamics varied through time and different treatments (Fig. 3a, b, Table 3). A loss of C could be observed in all substrates within the year-long decomposition. Spruce litter lost most $\mathrm{C}$ fraction in this original forest during the study period, while beech $\mathrm{C}$ in forest was released rapidly in the first three months and leveled out by the times, which was $6.6 \%$ faster on average for spruce in forest. 
Both, the spruce and beech did not show significance in the absolute amount of $\mathrm{N}$ release in one year period (Fig. 3c, d, p>0.05). $\mathrm{N}$ immobilization for both species appeared in forest after the first 47 days and almost up to its initial $\mathrm{N}$ amount. In clear-cuts, the $\mathrm{N}$ remaining generally decreased such that, on average, $9 \%$ of the total amount of $\mathrm{N}$ was released after one year of decomposition (Fig. 3c, d). Irrespective of species and soil types, decomposing litter in clear-cut mineralized relatively more $\mathrm{N}$ compared to the initial amount than in forest. There was no significant difference in the retention of $\mathrm{N}$ between soil types (Table 3).

The dynamic of litter nutrients release during decomposition

Most nutrients indicated significant mineralization over time (Fig. 3, Table 3), and observed net mineralization in all substrates following Fig. 3. Both leaf litter released P rapidly one year after the start of the decomposition, losing approximately $80 \%$ of their initial amount of P (Fig.3e, f, $p<0.001$ ),. Beech $(26 \%)$ retained more $\mathrm{P}$ than spruce $(18 \%)$ in one year period $(p<0.05)$. Fig. $3 \mathrm{e}$, f shows a similar pattern of P mineralization between forest and clear-cut for both species $(p>0.05)$. On average, the final Ca remaining was significantly higher in forest $(70 \%)$ than in clear-cut $(65 \%)$, regardless of species (Fig. $3 \mathrm{~g}, \mathrm{~h}$ ). Furthermore, the interaction between stands and soil types revealed that spruce Ca release was faster than beech (Fig. 3g, h, Table 3).

\section{Correlation between litter mass loss rate and residual quality}

Litter decomposition rate was associated with changing substrate quality in all subplots (Table 4). Decomposition rate of spruce in forest increased with litter $\mathrm{N}$ concentration, but decreased with litter Ca concentration $\left(R^{2}=0.97\right)$. Also, decomposition of spruce in clear-cut positively changed with $\mathrm{N}$, but negatively correlated with $\mathrm{P}$ concentration $\left(R^{2}=0.93\right)$. Beech decomposition rate in forests was positively related to $\mathrm{C}$ : $\mathrm{N}$ ratios $\left(R^{2}=0.67\right)$, but also decreased with litter Ca concentration when decomposed in clearcuts $\left(R^{2}=0.85\right)$.

\section{Isotopic change during decomposition}


The initial $\delta^{13} \mathrm{C}$ values were $-32.7 \%$ in beech leaves and were $-30.6 \%$ in spruce needles. The initial $\delta^{15} \mathrm{~N}$ values ranged from $-3.32 \%$ in beech leaves and $-4.70 \%$ in spruce needles (Fig. 4). The $\delta^{13} \mathrm{C}$ values of decomposing litters levelled off over time across litter types. The $\delta^{15} \mathrm{~N}$ values for both species was finally higher in clear-cut than in forest. In the first 9 months, $\delta^{15} \mathrm{~N}$ became enriched in all subplots, but then depleted in forest, while a larger decrease happened in Cambisol. Over the same period, the $\delta^{15} \mathrm{~N}$ value in clear-cut became higher throughout the experimental period in Cambisols $(-3.0$ and $-3.7 \%$ for beech and spruce, respectively), but it slightly dropped since July in moister Gleysols (-3.2 and $-4.1 \%$ for beech and spruce, respectively) (Fig. 4). Linear regression plots of $\mathrm{N}$ isotopic against $\mathrm{C}$ concentration (\%) were negatively significant among species over both stands ( $p<0.05$, Fig. S2). While the relationship of the $\delta^{13} \mathrm{C}$ values and $\mathrm{C}: \mathrm{N}$ was only linearly significant in forest for spruce $\left(R^{2}=0.83, P<0.01\right)$

\section{Discussion}

\section{Litter decomposition rates and HFA for spruce forest and clear-cut}

Our results indicated a positive effect of litter-site interaction on litter decomposition rate at home of $11 \%$ and $4 \%$ and thus a net HFA for both Norway spruce and European beech, which verified our first hypothesis. A meta-analysis have noticed that decomposition HFA is widespread in forest ecosystems with on average $4.2 \%$ promotion in the home habitat [46]. Low-quality spruce with low nutrients content and high C:N decomposed faster in spruce forest probably due to the presence of more fungal communities well adapted for degrading recalcitrant litter [31]. The decomposition of high-quality beech in clear-cut may have been dominated by bacterial communities which are better at the breakdown of more labile compounds, thus leading to a faster nutrients mineralization [31].

The input of soil organic matter and in particulate dissolved compounds originated from decomposition logging debris after clearcutting significantly improves soil nutrients and forest floor $\mathrm{pH}$ after a short-term regeneration from clearcutting [40]. This could account for to the lack of mean HFA for spruce in the clearcut. Suggesting that, thereby the existing nutrient-limited spruce forest was changed by the enhanced 
presence of labile compounds and associated soil microbes do quickly adapted to a new environment [8] and thus potentially masking the HFA for spruce already after a short-term regeneration.

\section{Decomposition and nutrient release of Norway spruce in original forest}

Decomposition and mineralization in initial phase is generally characterized by leaching of soluble nutrients and by decomposition of soluble and non-lignified cellulose and hemicellulose [48], which has been reported to be primarily controlled by major nutrients in litter [49]. Moreover, winter snow cover and snowmelt in this period fasten nutrients release and decomposition [50], resulting in a higher $k$ value in clear-cut versus forest, and thus no HFA was detected in initial 3-month decomposition.

The decomposition difference between litter types was correlated to the concentration of $\mathrm{C}$ and $\mathrm{N}$, and $\mathrm{C}$ : $\mathrm{N}$ ratios. Our results also corroborated this hypothesis that litter $\mathrm{N}$ concentration served as the most critical nutrient to regulate the degradation of spruce, and beech was decreased with increased $\mathrm{C}$ : $\mathrm{N}$ ratios, according to the stepwise regression (Table 4). Slower $\mathrm{N}$ release was detected in forest, which decreased litter $\mathrm{C}: \mathrm{N}$ ratios and promotes the generation of brown rot and white rot [51] and therefore fasten the degradation of the lignin-rich substrate (i.e., spruce). Also, faster spruce Ca release strengthen the soil acidification that maintain the soil $\mathrm{pH}$, sustaining the home-field effect. Although, litter quality well regulated the litter mass loss, litter quality independently did not serve as a predictor of mean HFA in this case (supplementary, Fig. S1). This result supported by evidence from Veen et al. [31]. This may because HFA is not restricted by single litter types, but the heterogeneity of litter quality between the 'home' and 'away' habitats [32]. Alternatively, the occurrence of HFA is likely system-dependent, suggesting that, transplants between labile litter from nutrient-rich ecosystems and recalcitrant litter from nutrient-limited ecosystems better induces HFA $[52,53]$. The results from this work were limited to spruce and beech only, a wider assessment of relevant controlling to determine the magnitude and the direction of HFA for plant traits.

Clearcutting promoted beech decomposition and nutrient release pattern 
Beech leaves decomposed faster during the first year in clear-cut, which is accompanied by an increase in the mineralization rate of $\mathrm{C}$ and $\mathrm{N}$ in leaves and higher in immobilization in spruce needles. In addition, the less HFA of $\mathrm{C}, \mathrm{N}$ release was observed after clearcutting. Thus, a transfer from spruce to beech would facilitate the potential utilization of nutrients by trees. The shift of dominated trees species by clearcutting treatment would inherently influence the regeneration in this site through litter input quality [40].

Decay rates for beech in both stands were tightly related to $\mathrm{C}: \mathrm{N}$ ratios. Beech with lower $\mathrm{C}$ : $\mathrm{N}$ ratios contributed to a faster decomposition rate for beech $(k=0.31$ on average) than spruce $(k=0.29$ on average) in clear-cuts. Changed environmental conditions would directly affect litter mass loss after rapid shifts in plant community composition [32], contributing to the relatively elevated mass-loss rate for beech in clearcuts than in spruce forests and the suppression of HFA effect for spruce. Moreover, removing the forest canopy shifts plant community in the short term and restructures the local fungal community in soil [25]. This would further hinder the decomposition and nutrients turnover rate in this successional stands.

\section{Soil moisture as mediator of litter decomposition and HFA}

Our results indicated that the decay of beech in clear-cuts differed between soil conditions, that is, beneath Cambisols, the decay rates of beech was significantly higher in clear-cuts than in the forest, and interestingly, it was faster than spruce in clear-cuts. However, a minor difference in clear-cut was observed when decomposing on Gleysols, as well as a decline in the HFA of decomposition and C concentration. Gleysols nearby the stream is more moister than Cambisols. Microbial berakdown is likely to be limited with a high soil moisture level [54], probably resulting in insignificant decomposition between species and stands. Additionally, given the importance of the water-driven decomposition determines a weak mass loss in low-quality litter [55,56], contributing to a similar $k$ value (from spruce) between soil types.

Across soil types, the results showed that lower HFA on the degradation of mass and C on Gleysol. A saturated soil environment has been identified to reduce soil microbial decomposition [57]. Also, soil 
microbial communities of high soil moisture are generally $\mathrm{N}$ limited due to the less nutrient availability [58], resulting in higher $\mathrm{N}$ accumulation and $\mathrm{N}$ release HFA in Gleysol.

\section{Dynamics of the natural abundance of $\delta^{13} C$ and $\delta^{15} N$ during decomposition}

Isotopic discrimination during litter decomposition has been observed in several studies involving selective consumption of various $\mathrm{C}$ compounds. Litter $\mathrm{C}$ concentration with $\delta^{15} \mathrm{~N}$ value in this case was negatively significant. This correlation signifies that $\delta^{15} \mathrm{~N}$ discrimination between litter types is due to the preferential recalcitrant fraction in substrates, which is consistent with several studies [35,59]. Microbial analysis suggests that ${ }^{15} \mathrm{~N}$ was transferred actively aboveground by saprotrophic fungi [60], via promotion in the lignin or tannin degradation by fungi-based microbes. Suggesting that, decreased ${ }^{15} \mathrm{~N}$ values by retaining more litter $\mathrm{N}$ from forest floor than from clear-cut does contribute to the higher microbial uptake and hence faster spruce litter $\mathrm{C}$ degradation in 'home' forest and thereby strengthens the HFA.

In our study, we found a negligible change of $\delta^{13} \mathrm{C}$ between stands during decomposition, residual $\mathrm{C}$ pools with slightly $\delta^{13} \mathrm{C}$ distinct were needed to account for the duration of the experiment. A report from Ngao and Cotrufo. [61] indicated litter $\delta^{13} \mathrm{C}$ discrimination appeared particularly in late stages of litter decomposition owing to the increase of the $\delta^{13} \mathrm{C}$ of decomposition litter $\alpha$-cellulose. Future long-term litter decomposition studies on the discrimination of natural abundance of isotope between species types and ecosystems are therefore recommended.

\section{Conclusion}

Spruce decomposed faster in spruce forest while beech decomposed faster in clear-cut, tightly associating with litter quality, indicating the occurrence of decomposition HFA at forest and clear-cut. Promoted decomposition and $\mathrm{C}$ mineralization for spruce in forest could be implied through relatively higher residual N concentration. Since the clear-cut in the 2013, plant community and soil environment had shifted the historical resources from original forest that facilitated faster beech decomposition and nutrients turnover rates due to lower $\mathrm{C}: \mathrm{N}$, thereby overriding pre-existing species HFA effects, especially at dryer 
Cambisols. $\delta^{15} \mathrm{~N}$ diverged after 9 months at Cambisol between forest and clear-cut, suggesting that litter $\mathrm{N}$ decomposition correlated to soil and residual $\mathrm{C}$ status. This has implications for the management of upland forests that are currently still under conifers: Their regeneration to more natural forests with European beech can be promoted in short-term by intensive forest management.

\section{Funding information}

This research received no external funding.

\section{Author contributions}

All authors have read and agreed to the published version of the manuscript.

Designed study concept: Liyan Zhuang, Roland Bol and Andrea Schnepf. Sample preparation, field sampling and obtained data: Liyan Zhuang, Ziyi Liang and Kirsten Unger. Wrote and revised the text: Liyan Zhuang, Roland Bol and Andrea Schnepf. All authors have read and agreed the published version of the manuscript.

\section{Conflict of interest and other ethics statements}

The authors declare no conflicts of interest.

\section{Reference}

1. Farber, S.; Costanza, R.; Childers, D.L.; Erickson, J.; Gross, K.; Grove, M.; Hopkinson, C.S.; Kahn, J.; Pincetl, S.; Troy, A.; Warren, P.; Wilson, M. Linking Ecology and Economics for Ecosystem Management. BioScience 2006, 56, 121-133.

2. Both, S.; Elias, D.M.; Kritzler, U.H.; Ostle, N.J.; Johnson, D. Land use not litter quality is a stronger driver of decomposition in hyperdiverse tropical forest. Ecology and Evolution 2017, 7, 9307-9318.

3. Mayer, M.; Prescott, C.E.; Abaker, W.E.; Augusto, L.; Cécillon, L.; Ferreira, G.W.; James, J.; Jandl, R.; Katzensteiner, K.; Laclau, J.-P. Influence of forest management activities on soil organic carbon stocks: A knowledge synthesis. Forest Ecology and Management 2020, 466, 118127.

4. Achilles, F.; Tischer, A.; Bernhardt-Romermann, M.; Heinze, M.; Reinhardt, F.; Makeschin, F.; Michalzik, B. European beech leads to more bioactive humus forms but stronger mineral soil 
acidification as Norway spruce and Scots pine - Results of a repeated site assessment after 63 and 82 years of forest conversion in Central Germany. Forest Ecology and Management 2021, 483, 15.

5. Trap, J.; Bureau, F.; Brethes, A.; Jabiol, B.; Ponge, J.-F.; Chauvat, M.; Decaens, T.; Aubert, M. Does moder development along a pure beech (Fagus sylvatica L.) chronosequence result from changes in litter production or in decomposition rates? Soil Biology \& Biochemistry 2011, 43, 14901497.

6. Xuluc-Tolosa, F.J.; Vester, H.F.M.; Ramı; x; rez-Marcial, N.; Castellanos-Albores, J.; Lawrence, D. Leaf litter decomposition of tree species in three successional phases of tropical dry secondary forest in Campeche, Mexico. Forest Ecology and Management 2003, 174, 401-412.

7. Zhang, W.; Gao, D.X.; Chen, Z.X.; Li, H.; Deng, J.; Qiao, W.J.; Han, X.H.; Yang, G.H.; Feng, Y.Z.; Huang, J.Y. Substrate quality and soil environmental conditions predict litter decomposition and drive soil nutrient dynamics following afforestation on the Loess Plateau of China. Geoderma 2018, 325, 152-161.

8. Allison, S.D.; Lu, Y.; Weihe, C.; Goulden, M.L.; Martiny, A.C.; Treseder, K.K.; Martiny, J.B.H. Microbial abundance and composition influence litter decomposition response to environmental change. Ecology 2013, 94, 714-725.

9. Gautam, M.K.; Lee, K.S.; Song, B.Y.; Lee, D.; Bong, Y.S. Early-stage changes in natural (13)C and $(15) \mathrm{N}$ abundance and nutrient dynamics during different litter decomposition. J Plant Res 2016, $129,463-476$.

10. Spiecker, H. Norway spruce conversion: Options and consequences. Leiden,2004.

11. Otto, H.J. Die verwirklichung des LÖWE_Regierungsprogramms. . AFZ/Wald 1995, 50, 10269.

12. Wulf, M. Forest policy in the EU and its influence on the plant diversity of woodlands. Journal of environmental management 2003, 67, 15-25.

13. Asplund, J.; Kauserud, H.; Bokhorst, S.; Lie, M.H.; Ohlson, M.; Nybakken, L. Fungal communities influence decomposition rates of plant litter from two dominant tree species. Fungal Ecology 2018, $32,1-8$.

14. Berger, T.W.; Berger, P. Greater accumulation of litter in spruce (Picea abies) compared to beech (Fagus sylvatica) stands is not a consequence of the inherent recalcitrance of needles. Plant and Soil 2012, 358, 349-369.

15. Vesterdal, L. Influence of soil type on mass loss and nutrient release from decomposing foliage litter of beech and Norway spruce. Canadian Journal of Forest Research 1999, 29, 95-105.

16. Liu, Q.; Zhuang, L.; Yin, R.; Ni, X.; You, C.; Yue, K.; Tan, B.; Liu, Y.; Zhang, L.; Xu, Z. Root diameter controls the accumulation of humic substances in decomposing root litter. Geoderma 2019, $348,68-75$.

17. Fanin, N.; Bertrand, I. Aboveground litter quality is a better predictor than belowground microbial communities when estimating carbon mineralization along a land-use gradient. Soil Biology and Biochemistry 2016, 94, 48-60.

18. Gholz, H.L.; Wedin, D.A.; Smitherman, S.M.; Harmon, M.E.; Parton, W.J. Long-term dynamics of pine and hardwood litter in contrasting environments: toward a global model of decomposition. Global Change Biology 2000, 6, 751-765.

19. Ayres, E.; Steltzer, H.; Simmons, B.L.; Simpson, R.T.; Steinweg, J.M.; Wallenstein, M.D.; Mellor, N.; Parton, W.J.; Moore, J.C.; Wall, D.H. Home-field advantage accelerates leaf litter decomposition in forests. Soil Biology and Biochemistry 2009, 41, 606-610.

20. Kang, H.; Gao, H.; Yu, W.; Yi, Y.; Wang, Y.; Ning, M. Changes in soil microbial community structure and function after afforestation depend on species and age: Case study in a subtropical alluvial island. Science of The Total Environment 2018, 625, 1423-1432.

21. Prescott, C.E.; Blevins, L.L.; Staley, C.L. Effects of clear-cutting on decomposition rates of litter and forest floor in forests of British Columbia. Canadian Journal of Forest Research-Revue Canadienne De Recherche Forestiere 2000, 30, 1751-1757. 
22. Ishikawa, H.; Osono, T.; Takeda, H. Effects of clear-cutting on decomposition processes in leaf litter and the nitrogen and lignin dynamics in a temperate secondary forest. Journal of Forest Research 2007, 12, 247-254.

23. Achat, D.L.; Deleuze, C.; Landmann, G.; Pousse, N.; Ranger, J.; Augusto, L. Quantifying consequences of removing harvesting residues on forest soils and tree growth - A meta-analysis. Forest Ecology and Management 2015, 348, 124-141.

24. Carnol, M.; Bazgir, M. Nutrient return to the forest floor through litter and throughfall under 7 forest species after conversion from Norway spruce. Forest Ecology and Management 2013, 309, 66-75.

25. Kohout, P.; Charvátová, M.; Štursová, M.; Mašínová, T.; Tomšovský, M.; Baldrian, P. Clearcutting alters decomposition processes and initiates complex restructuring of fungal communities in soil and tree roots. the ISME Journal 2018, 12, 692.

26. Finér, L.; Jurgensen, M.; Palviainen, M.; Piirainen, S.; Page-Dumroese, D. Does clear-cut harvesting accelerate initial wood decomposition? A five-year study with standard wood material. Forest Ecology and Management 2016, 372, 10-18.

27. Gliksman, D.; Haenel, S.; Osem, Y.; Yakir, D.; Zangy, E.; Preisler, Y.; Grünzweig, J.M. Litter decomposition in Mediterranean pine forests is enhanced by reduced canopy cover. Plant and Soil 2018, 422, 317-329.

28. Keiser, A.D.; Keiser, D.A.; Strickland, M.S.; Bradford, M.A. Disentangling the mechanisms underlying functional differences among decomposer communities. Journal of Ecology 2014, 102, 603-609.

29. Wardle, D.A.; Bardgett, R.D.; Klironomos, J.N.; Setälä, H.; Van Der Putten, W.H.; Wall, D.H. Ecological linkages between aboveground and belowground biota. Science 2004, 304, 1629-1633.

30. Chomel, M.; Guittonny-Larchevêque, M.; DesRochers, A.; Baldy, V. Home Field Advantage of Litter Decomposition in Pure and Mixed Plantations Under Boreal Climate. Ecosystems 2015, 18, 1014-1028.

31. Veen, G.F.; Sundqvist, M.K.; Wardle, D.A. Environmental factors and traits that drive plant litter decomposition do not determine home-field advantage effects. Functional Ecology 2015, 29, 981991.

32. Veen, G.F.; Freschet, G.T.; Ordonez, A.; Wardle, D.A. Litter quality and environmental controls of home-field advantage effects on litter decomposition. Oikos 2015, 124, 187-195.

33. Michener, R.; Lajtha, K. Stable isotopes in ecology and environmental science. John Wiley \& Sons, 2008 .

34. Gautam, M.K.; Lee, K.-S.; Song, B.-Y.; Lee, D.; Bong, Y.-S. Early-stage changes in natural 13 C and $15 \mathrm{~N}$ abundance and nutrient dynamics during different litter decomposition. Journal of plant research 2016, 129, 463-476.

35. Osono, T.; Takeda, H.; Azuma, J.-i. Carbon isotope dynamics during leaf litter decomposition with reference to lignin fractions. Ecological research 2008, 23, 51-55.

36. Dijkstra, P.; LaViolette, C.M.; Coyle, J.S.; Doucett, R.R.; Schwartz, E.; Hart, S.C.; Hungate, B.A. $15 \mathrm{~N}$ enrichment as an integrator of the effects of $\mathrm{C}$ and $\mathrm{N}$ on microbial metabolism and ecosystem function. Ecology letters 2008, 11, 389-397.

37. Pardo, L.H.; Hemond, H.F.; Montoya, J.P.; Fahey, T.J.; Siccama, T.G. Response of the natural abundance of $15 \mathrm{~N}$ in forest soils and foliage to high nitrate loss following clear-cutting. Canadian Journal of Forest Research 2002, 32, 1126-1136.

38. Hobbie, S.E.; Vitousek, P.M. Nutrient limitation of decomposition in Hawaiian forests. Ecology 2000, 81, 1867-1877.

39. Jiang, C.; Séquaris, J.-M.; Vereecken, H.; Klumpp, E. Effects of temperature and associated organic carbon on the fractionation of water-dispersible colloids from three silt loam topsoils under different land use. Geoderma 2017, 299, 43-53.

40. Siebers, N.; Kruse, J. Short-term impacts of forest clear-cut on soil structure and consequences for organic matter composition and nutrient speciation: A case study. PLOS ONE 2019, 14, e0220476. 
41. Rosenbaum, U.; Bogena, H.R.; Herbst, M.; Huisman, J.A.; Peterson, T.J.; Weuthen, A.; Western, A.W.; Vereecken, H. Seasonal and event dynamics of spatial soil moisture patterns at the small catchment scale. Water resources research 2012, 48, 1-22.

42. Wiekenkamp, I.; Huisman, J.A.; Bogena, H.R.; Graf, A.; Lin, H.S.; Druee, C.; Vereecken, H. Changes in measured spatiotemporal patterns of hydrogical response after partial deforestation in a headwater catchemnt. Journal of Hydrology 2016, 542, 648-661.

43. Havlik, D. Das Klima von Aachen. Aachener Geographische Arbeiten 2002, 36, 1-20.

44. Etmann, M. Dendrologische aufnahmen im wassereinzugsgebiet oberer wüstebach anhand verschiedener mess-und schätzverfahren. Westfälische Wilhelms-Universität, Münster, Germany 2009, 25.

45. Bradford, M.A.; Tordoff, G.M.; Eggers, T.; Jones, T.H.; Newington, J.E. Microbiota, fauna, and mesh size interactions in litter decomposition. Oikos 2002, 99, 317-323.

46. Wang, Q.K.; Zhong, M.C.; He, T.X. Home-field advantage of litter decomposition and nitrogen release in forest ecosystems. Biology and Fertility of Soils 2013, 49, 427-434.

47. Olson, J.S. Energy storage and the balance of producers and decomposers in ecological systems. Ecology 1963, 44, 322-331.

48. Heim, A.; Frey, B. Early stage litter decomposition rates for Swiss forests. Biogeochemistry 2004, 70, 299-313.

49. García - Palacios, P.; Shaw, E.A.; Wall, D.H.; Hättenschwiler, S. Temporal dynamics of biotic and abiotic drivers of litter decomposition. Ecology letters 2016, 19, 554-563.

50. McDowell, N.G.; Allen, C.D.; Marshall, L. Growth, carbon-isotope discrimination, and droughtassociated mortality across a Pinus ponderosa elevational transect. Global Change Biology 2010, 16, 399-415.

51. Rajala, T.; Peltoniemi, M.; Hantula, J.; Mäkipää, R.; Pennanen, T. RNA reveals a succession of active fungi during the decay of Norway spruce logs. Fungal Ecology 2011, 4, 437-448.

52. St John, M.G.; Orwin, K.H.; Dickie, I.A. No 'home' versus 'away' effects of decomposition found in a grassland-forest reciprocal litter transplant study. Soil Biology \& Biochemistry 2011, 43, 14821489.

53. Freschet, G.T.; Aerts, R.; Cornelissen, J.H.C. Multiple mechanisms for trait effects on litter decomposition: moving beyond home-field advantage with a new hypothesis. Journal of Ecology 2012, 100, 619-630.

54. Petraglia, A.; Cacciatori, C.; Chelli, S.; Fenu, G.; Calderisi, G.; Gargano, D.; Abeli, T.; Orsenigo, S.; Carbognani, M. Litter decomposition: effects of temperature driven by soil moisture and vegetation type. Plant and Soil 2019, 435, 187-200.

55. Cotrufo, M.F.; Soong, J.L.; Horton, A.J.; Campbell, E.E.; Haddix, Michelle L.; Wall, D.H.; Parton, W.J. Formation of soil organic matter via biochemical and physical pathways of litter mass loss. Nature Geoscience 2015, 8, 776.

56. Mansfield, S.D.; Bärlocher, F. Determination of Soluble Carbohydrates. In: Methods to Study Litter Decomposition: A Practical Guide (eds. Graça, Manuel A. S.;Bärlocher, FelixGessner, Mark O.). Springer Netherlands Dordrecht,2005, p.`pp. 85-90.

57. Ahmed, I.U.; Mengistie, H.K.; Godbold, D.L.; Sandén, H. Soil moisture integrates the influence of land-use and season on soil microbial community composition in the Ethiopian highlands. Applied Soil Ecology 2019, 135, 85-90.

58. Mueller, P.; Schile-Beers, L.M.; Mozdzer, T.J.; Chmura, G.L.; Dinter, T.; Kuzyakov, Y.; de Groot, A.V.; Esselink, P.; Smit, C.; D'Alpaos, A.; Ibáñez, C.; Lazarus, M.; Neumeier, U.; Johnson, B.J.; Baldwin, A.H.; Yarwood, S.A.; Montemayor, D.I.; Yang, Z.; Wu, J.; Jensen, K.; Nolte, S. Globalchange effects on early-stage decomposition processes in tidal wetlands - implications from a global survey using standardized litter. Biogeosciences 2018, 15, 3189-3202.

59. Preston, C.M.; Nault, J.R.; Trofymow, J.A. Chemical Changes During 6 Years of Decomposition of 11 Litters in Some Canadian Forest Sites. Part 2. 13C Abundance, Solid-State 13C NMR Spectroscopy and the Meaning of "Lignin". Ecosystems 2009, 12, 1078-1102. 
60. Hobbie, E.A.; Högberg, P. Nitrogen isotopes link mycorrhizal fungi and plants to nitrogen dynamics. New phytologist 2012, 196, 367-382.

61. Ngao, J.; Cotrufo, M.F. Carbon isotope discrimination during litter decomposition can be explained by selective use of substrate with differing $<\mathrm{i}>\&$ delta; $</ \mathrm{i}><$ sup $>13</$ sup $>$ C. Biogeosciences Discuss. 2011, 2011, 51-82. 


\section{Tables and Figures}

2 Table 1 Nutrient concentrations and compound ratios of beech and spruce litter before and after one year

3 of decomposition.

\begin{tabular}{|c|c|c|c|c|c|c|}
\hline & \multicolumn{2}{|c|}{ Initial litter quality } & \multicolumn{4}{|c|}{ Residual quality after 1year of decomposition } \\
\hline & \multirow[t]{2}{*}{ Beech } & \multirow[t]{2}{*}{ Spruce } & \multicolumn{2}{|l|}{ Forest } & \multicolumn{2}{|l|}{ Clear-cut } \\
\hline & & & Beech & Spruce & Beech & Spruce \\
\hline $\mathrm{C}(\%)$ & $47.1 \pm 0.2 \mathrm{a}$ & $48.4 \pm 0.1 b$ & $48.2 \pm 0.8 \mathrm{a}$ & $49.5 \pm 0.6 b$ & $46.1 \pm 0.6 \mathrm{a}$ & $47.9 \pm 0.5 b$ \\
\hline $\mathrm{N}(\%)$ & $2.1 \pm 0.1 \mathrm{a}$ & $1.2 \pm 0.0 \mathrm{~b}$ & $3.0 \pm 0.1 \mathrm{a}$ & $1.9 \pm 0.8 b$ & $2.8 \pm 0.1 \mathrm{a}$ & $1.6 \pm 0.1 b$ \\
\hline $\mathrm{P}\left(\mathrm{mg} \mathrm{kg}^{-1}\right)$ & $278.4 \pm 10.4 \mathrm{a}$ & $254.9 \pm 8.6 b$ & $105.2 \pm 6.3 \mathrm{a}$ & $81.0 \pm 8.9 b$ & $104.5 \pm 6.0 \mathrm{a}$ & $61.5 \pm 4.9 b$ \\
\hline $\mathrm{C}: \mathrm{N}$ & $22.4 \pm 0.5 \mathrm{a}$ & $39.0 \pm 1.3 b$ & $20.2 \pm 0.6 \mathrm{a}$ & $34.4 \pm 0.7 b$ & $20.8 \pm 0.8 \mathrm{a}$ & $35.1 \pm 0.4 b$ \\
\hline $\operatorname{Mg}\left(\mathrm{mg} \mathrm{kg}^{-1}\right)$ & $519.2 \pm 6.0 \mathrm{a}$ & $185.4 \pm 1.5 b$ & $157.5 \pm 30.3 \mathrm{a}$ & $58.9 \pm 10.4 \mathrm{~b}$ & $172.2 \pm 33.0 \mathrm{a}$ & $48.6 \pm 8.7 b$ \\
\hline $\mathrm{Ca}\left(\mathrm{mg} \mathrm{kg}^{-1}\right)$ & $2.18 \pm 0.04 \mathrm{a}$ & $1.67 \pm 0.01 b$ & $1.02 \pm 0.09 \mathrm{a}$ & $0.74 \pm 0.08 \mathrm{~b}$ & $1.20 \pm 0.05 \mathrm{a}$ & $0.79 \pm 0.06 b$ \\
\hline $\operatorname{Mn}\left(\mathrm{mg} \mathrm{kg}^{-1}\right)$ & $180.6 \pm 1.9 \mathrm{a}$ & $158.9 \pm 3.6 \mathrm{~b}$ & $88.9 \pm 21.7 \mathrm{a}$ & $62.1 \pm 15.6 b$ & $78.6 \pm 20.0 \mathrm{a}$ & $40.2 \pm 11.4 \mathrm{~b}$ \\
\hline
\end{tabular}

4 The lower-case letter indicates significance between species at same stands.

5

6

7

8 9

Table 2 Home-field advantage of mass loss and of $\mathrm{C}$ and $\mathrm{N}$ release for spruce and beech liter in forest and clear-cut.

\begin{tabular}{llll}
\hline & Cambisol & Gleysol & 10 \\
\hline Mass loss & $11.2 \pm 0.5 \mathrm{a}$ & $3.7 \pm 1.0 \mathrm{~b}$ & \\
C release & $14.0 \pm 2.5 \mathrm{a}$ & $10.7 \pm 0.9 \mathrm{~b}$ & \\
N release & $28.3 \pm 0.9 \mathrm{a}$ & $43.1 \pm 5.4 \mathrm{~b}$ & \\
\hline
\end{tabular}

11 The lower-case letter indicates significance between stands.

12 
14 Table 3 Three-way ANOVA analysis of $F$-value on the effect of soil types, stands, species, and their

15 interactions on nutrient remaining over decomposition.

\begin{tabular}{llllllll}
\hline & \multicolumn{7}{c}{ Remaining } \\
\cline { 2 - 7 } & $d f$ & $\mathrm{C}$ & $\mathrm{N}$ & $\mathrm{P}$ & $\mathrm{Mg}$ & $\mathrm{Ca}$ & $\mathrm{Mn}$ \\
\hline Soil type & 1 & $6.8^{*}$ & 0.7 & $8.4^{*}$ & 2.7 & 0.1 & 1.3 \\
Stand $\times$ Soil type & 1 & 2.9 & 2.1 & 4.3 & 0.7 & $15.6^{* *}$ & $12.1^{* *}$ \\
Soil type $\times$ Species & 1 & $31.6^{* * *}$ & 0.6 & 0.0 & 2.0 & 0.0 & 1.0 \\
Stand $\times$ Soil type $\times$ Species & 1 & $6.3^{*}$ & 1.3 & $8.5^{*}$ & 1.6 & 3.2 & 0.8 \\
\hline
\end{tabular}

16

*: $p<0.05 ;{ }^{* *}: p<0.01 ; * * *: p<0.001$.

17 
18 Table 4 Stepwise regression of the correlation between litter mass loss rate and nutrient concentrations 19 and stoichiometry of beech and spruce under forest and clear-cut over decomposition. Data indicates

20 significant variables related to decomposition, followed by $R^{2}$.

\begin{tabular}{clll}
\hline & variables & Coefficients & $R^{2}$ \\
\hline \multicolumn{1}{c}{ Spruce } & & & \\
\cline { 1 - 1 } Clear-cut & $\mathrm{N}, \mathrm{P}$ & $0.65,-0.36$ & 0.93 \\
Forest & $\mathrm{N}, \mathrm{Ca}$ & $0.77,-0.23$ & 0.97 \\
\cline { 1 - 1 } Beech & & & \\
\cline { 1 - 1 } Clear-cut & Ca, C:N & $-0.51,-0.49$ & 0.85 \\
Forest & C:N & -0.82 & 0.66 \\
\hline
\end{tabular}

21

22 

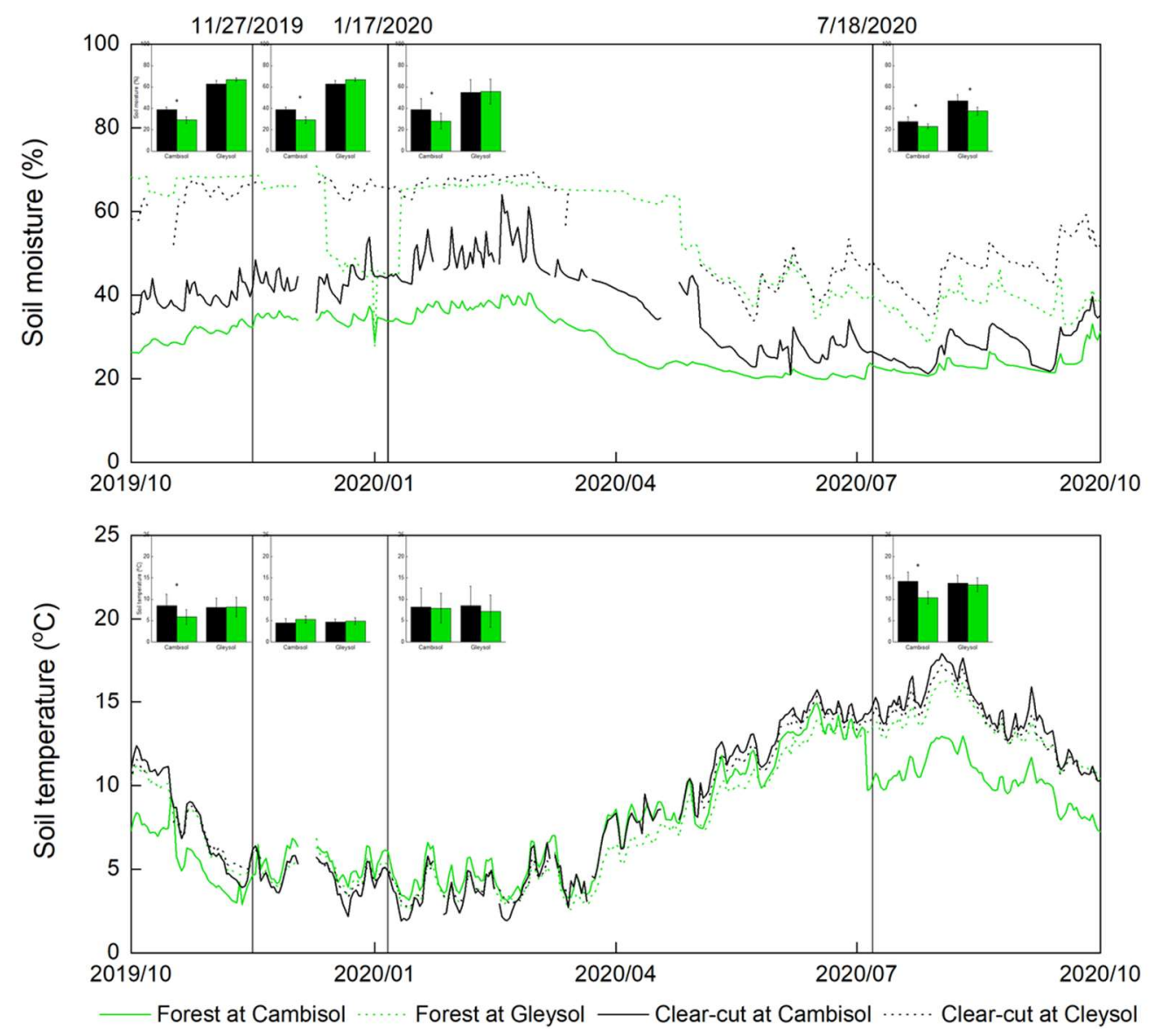

23 Fig. 1 The dynamic of soil moisture $(\%)$ and temperature $\left({ }^{\circ} \mathrm{C}\right)$ in the top layer during one year of 24 decomposition. Bar charts indicate mean values with error bars at each sampling time. The green bar 25 indicated forest, the black bar indicated forest. $* p<0.05$. 
26 Fig. $2 k$-values $\left(\mathrm{yr}^{-1}\right)$ of beech and 27 spruce in clear-cut and forest at
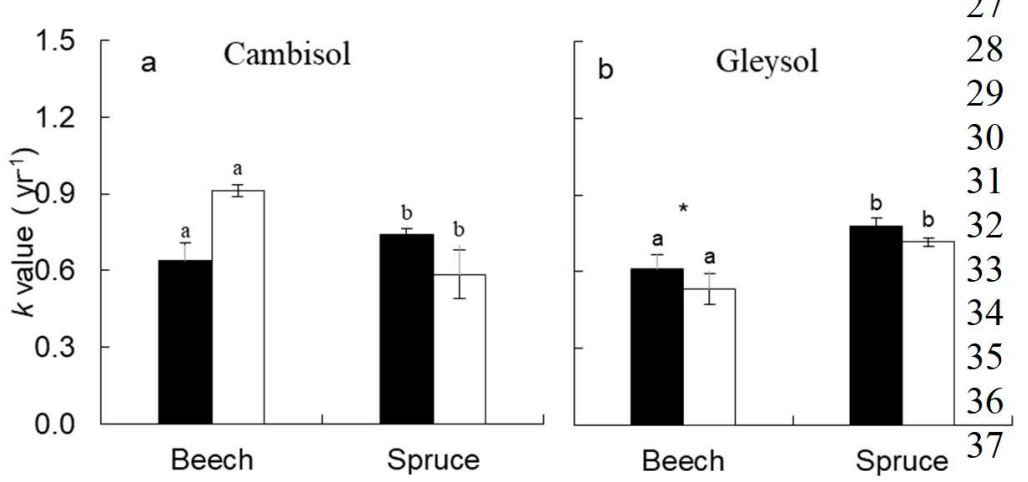
Cambisols and Gleysols after 3 months $(a, b)$ and one year (c, d) of decomposition.

$*: p<0.05 ; * *: p<0.01 ; * * *: p<0.001$ indicate significance between stands with same species; Lower-case letters indicated significance between species at same stands.
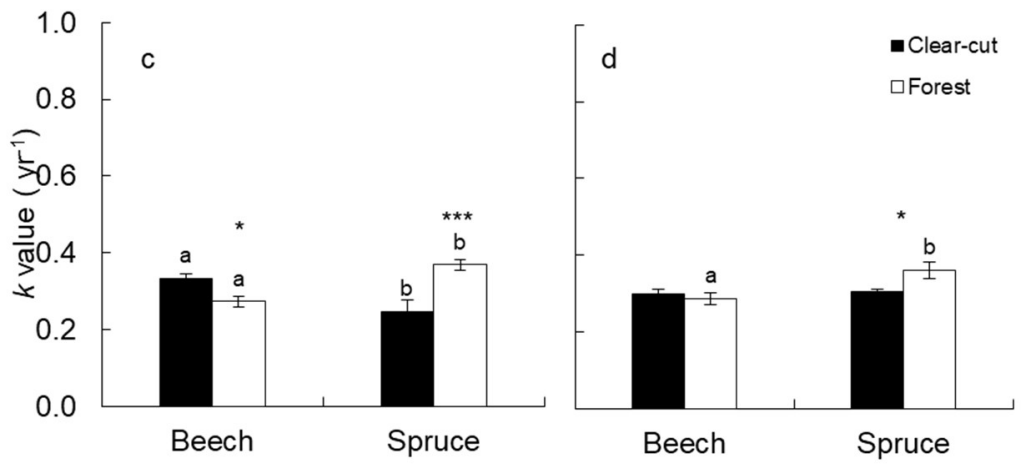

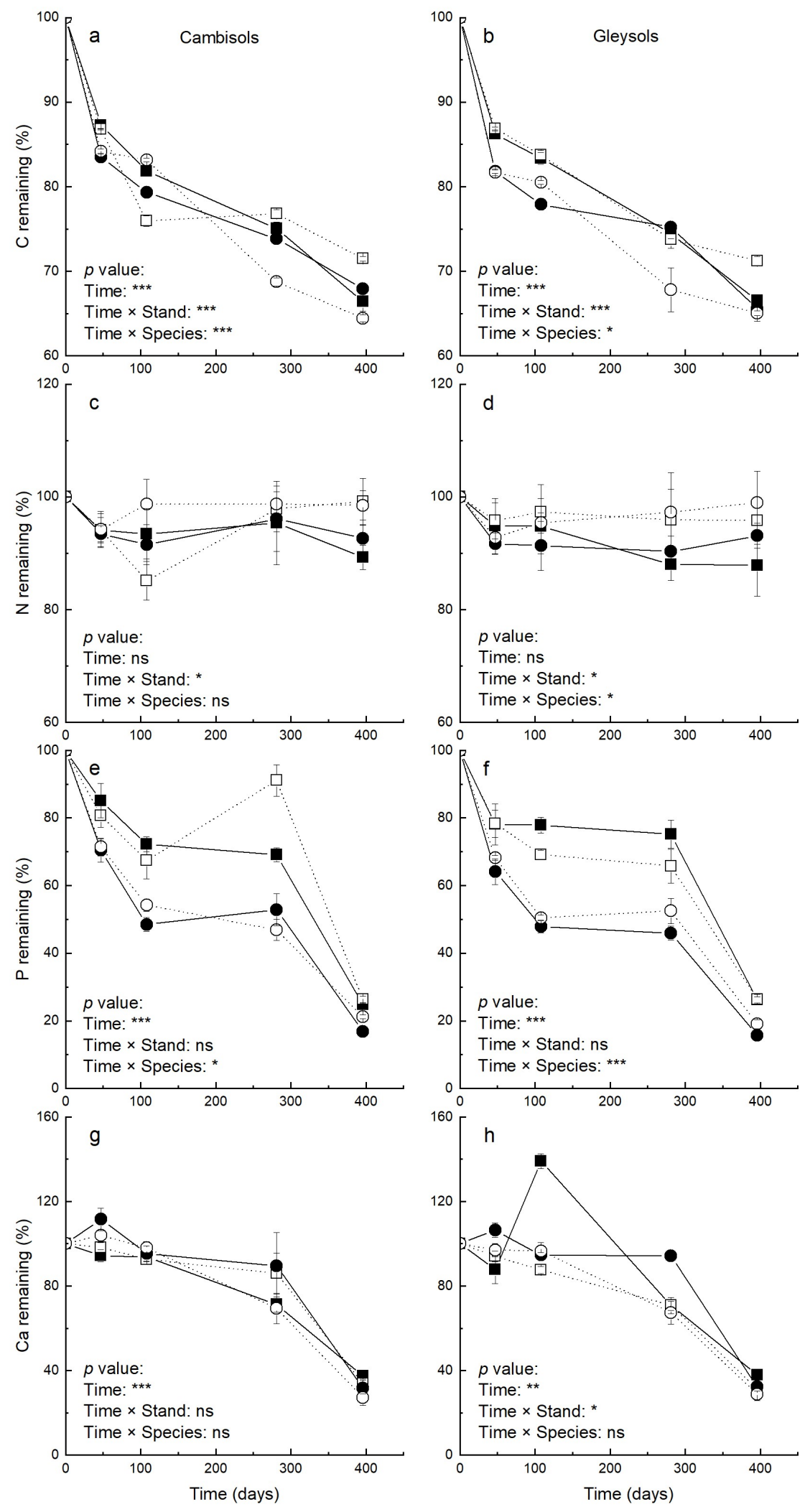

- Beech in clear-cut $\cdots \square \cdots$ Beech in forest
Spruce in clear-cut $\cdots O \cdots$ Spruce in forest
Fig. 3 Nutrients $(\mathrm{C}, \mathrm{N}, \mathrm{P}$ and $\mathrm{Ca}$ ) remaining of beech and spruce at different plots over one year of decomposition. Error bars respective standard error. Repeated measure ANOVA indicated significance of stand and species with time periods: ns $p>0.05, * p<0.05$, ** $p<0.01,{ }^{* * *} p<0.001$. 

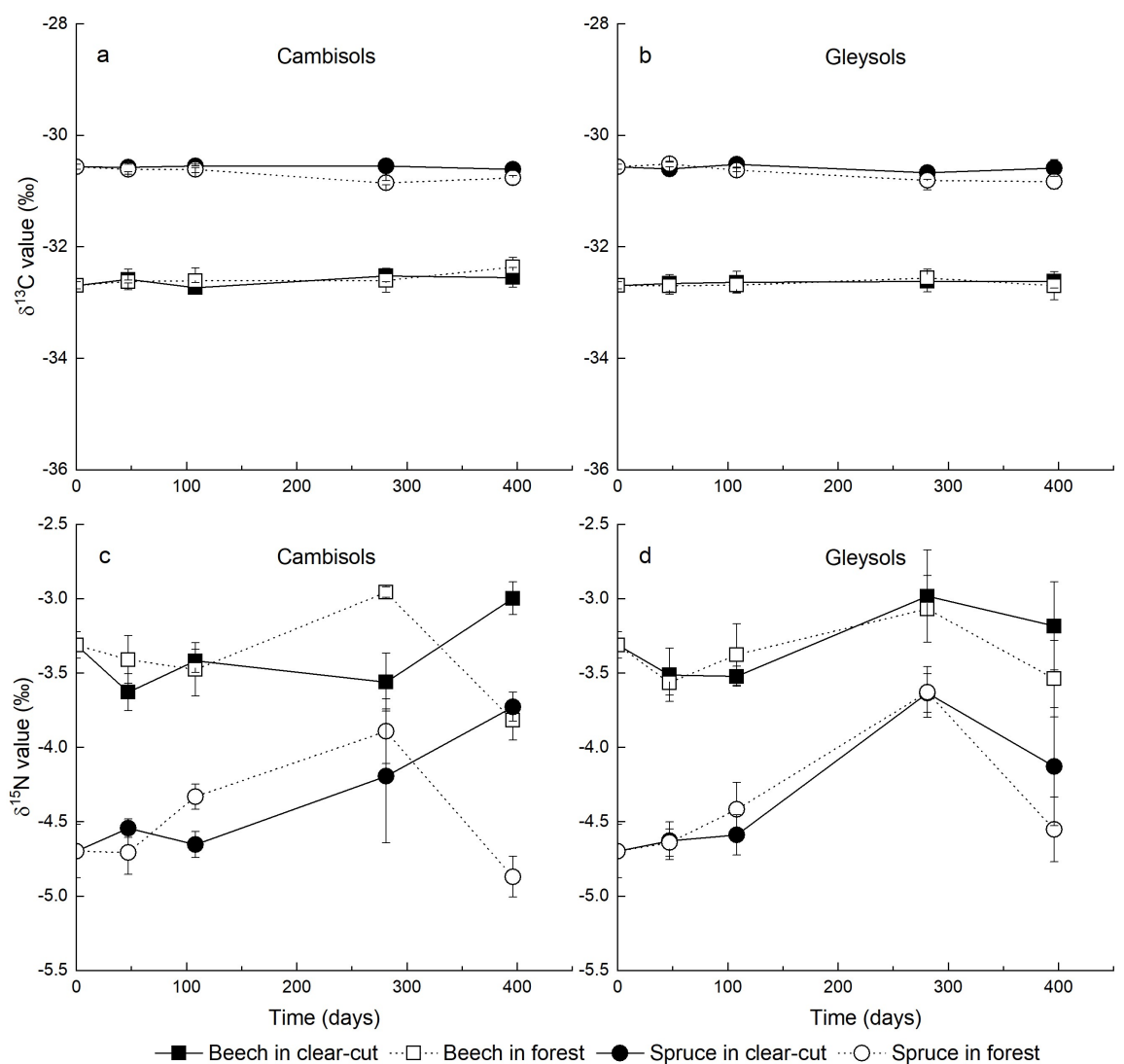

Fig. 4 The change of isotopic ${ }^{13} \mathrm{C}$ and $\delta^{15} \mathrm{~N}$ value of beech and spruce over one year of decomposition. Error 54 bars respective standard error. 